Izabela Kozłowska (iza.tarka@wp.pl)

\title{
Modele rewitalizacji XIX-wiecznych obszarów miejskich na przykładzie Szczecina
}

\section{The models of the revitalization of the $19^{\text {th }}$ urban space on the example of Szczecin}

\section{Streszczenie}

Śródmiejskie dzielnice Szczecina: Centrum, Śródmieście-Zachód oraz Turzyn są obszarami miejskimi, które powstały w wyniku rozbudowy miasta na przełomie XIX i XX w. Ten obszar Śródmieścia, posiadający obecnie budynki o niskim standardzie bytowo-mieszkaniowym i technicznym, od 1992 r. stał się polem długoletnich działań rewitalizacyjnych i proekologicznych, które przedstawione zostaną w niniejszym artykule.

Słowa kluczowe: rewitalizacja, Szczecin, Śródmieście, XIX-wieczne obszary miejskie

Abstract

Downtown districts of Szczecin: Centrum, Śródmieście-Zachód and Turzyn are urban areas that were created as a result of the expansion of the city at the turn of the 19th and 20th centuries. The field of long-term revitalization and ecological activities, which will be presented in this article.

Keywords: revitalization, Szczecin, Śródmieście, $19^{\text {th }}$ century urban areas 


\section{WSTĘP}

Śródmiejskie dzielnice: Szczecin-Centrum, Śródmieście-Zachód, Turzyn są obszarami miejskimi, które powstały w wyniku rozbudowy miasta na przełomie XIX i XX w. Impulsem do ich powstania była decyzja o defortyfikacji Szczecina podjęta przez władze pruskie w 1873 r. Miasto uwolnione od „ciasnego gorsetu” fortyfikacji nowożytnych rozpoczęło swój rozwój przestrzenny w kierunku północno-zachodnim na miejscu dawnych pruskich fortów: Wilhelm i Leopold. Zabudowa nowej dzielnicy ukończona została w przeciągu 3 dekad, będąc świadectwem niezwykle intensywnego rozwoju demograficzno-przestrzennego Szczecina, jaki dokonał się na przełomie XIX i XX w.

Obszar śródmiejski Szczecina charakteryzuje się wysokimi walorami historyczno-kulturowymi i jest przykładem unikatowego na tle polskich miast XIX-wiecznego założenia miejskiego. Wartość zespołu dostrzeżono na początku przemian ustrojowych, świadomie kształtując dla tego obszaru politykę przestrzenną od 1990 r. Podjęte działania wynikały nie tylko z chęci ratowania dziedzictwa kulturowego, ale przed wszystkim ze stanu degradacji przestrzennej i społecznej panującej w obszarach śródmiejskich. Katastrofalna sytuacja Śródmieścia wymagała zastosowania nowego narzędzia - rewitalizacji, która „(...) ma charakter kompleksowy, wzajemnie uzupełniających się i wzmacniających działań, mających na celu wywołanie jakościowej pozytywnej zmiany na obszarze o zidentyfikowanych cechach degradacji"1.

\section{REWITALIZACJA XIX-WIECZNEGO OBSZARU SZCZECINA}

Władze miasta kompleksowe działania rewitalizacyjne zainicjowały od rozpoznania mieszkaniowego zasobu Śródmieścia oraz zdiagnozowania kluczowych problemów związanych z zabudową mieszkaniową. Przeprowadzona analiza wykazała niski standard mieszkań (brak łazienek, ogrzewanie piecami węglowymi, wspólne toalety na półpiętrach lub podwórzach, brak spłukiwanych ustępów), zły stan techniczny obiektów, niską efektywność energetyczną budynków, duże zagęszczenie zabudowy, chaos przestrzenny panujący na podwórzach pozbawionych zieleni oraz elementów małej architektury i rekreacji czy problemy związane z niskim statusem materialnym i społecznym mieszkańców kamienic. Pierwszą konkluzją było uznanie potrzeby ratowania historycznej zabudowy poprzez przeprowadzenie kompleksowych działań modernizacyjnych kwartałów. Po udzielenie pomocy doradczej władze miejskie skierowały się do ONZ uzyskując takie wsparcie w ramach Programu Umbrella. Poczynione kroki pozwoliły na utworzenie działającego w ramach magistratu szczecińskiego Zespołu Koordynacji ds. Renowacji, który opracował w 1992 r. Strategię Renowacji Śródmieścia Szczecin uchwaloną przez Radę Miejską w 1993 roku². Ten akt prawa miejskiego stał się bazą dla formułowania kolejnych dokumentów poświęconych polityce przestrzennej Szczecina. I tak w 2005 r. został uchwalony Lokalny Program Rewitalizacji obszarów 
miejskich, poprzemysłowych i powojskowych miasta Szczecina, a w 2010 r. Lokalny Program Rewitalizacji dla Miasta Szczecina aktualizowany w latach 2014 i $2017^{3}$. W tym miejscu należy podkreślić, że rewitalizacja zainicjowana w Szczecinie w 1991 r. była pierwszą, jaką podjęto na XIX-wiecznych obszarach miejskich w Polsce.

Obszarem działań rewitalizacyjnych objęto w sumie 56 kwartałów rozciągających się na 205 ha, które zamieszkuje ok. 50 tys. mieszkańców4 .

W 1993 r. Miasto przystąpiło do wdrażania dwóch pilotażowych programów rewitalizacyjnych, charakteryzujących się odmiennymi formułami finansowania i współpracy. W kwartale $\mathrm{nr} 27$ pilotowano model budżetowy z finansowaniem publicznym, natomiast w kwartale nr 21 wdrażany był model komercyjny. Oba programy były doświadczalnymi, innowacyjnymi projektami, które wyznaczyły kierunek działań podejmowanych podczas rewitalizacji kolejnych obszarów Szczecina.

Pierwotnie zarządzanie inwestycjami nadzorowała miejska administracja. Po 1997 r. kierowanie pracami przejęły spółki miejskie należące w 100\% do Gminy Miasta Szczecin: Szczecińskie Towarzystwo Budownictwa Społecznego Sp. z o.o. (STBS) założone w 1997 r. oraz od 1999 r. Szczecińskie Centrum Renowacyjne Sp. z o.o. (SCR), którego kapitał po jej likwidacji w 2013 r. przejęło Towarzystwo Budownictwa Społecznego Prawobrzeże Sp. z o.o. (TBSP) ${ }^{5}$.

Wieloletnie doświadczenia na polu rewitalizacji zaowocowały wypracowaniem przez władze miasta różnych modeli realizacji inwestycji oraz programów wspierających te działania, które ewoluowały wraz ze zmianami w zakresie: źródeł dofinansowania, partnerów komercyjnych, instrumentów formalno-prawnych oraz definicji rewitalizacji, którą z czasem poszerzono o elementy zrównoważonego rozwoju.

\subsection{MODEL BUDŻETOWY REALIZOWANY POPRZEZ FINANSOWANIE PUBLICZNE}

Kwartał nr 27, tzw. „turzyński” był pierwszym obszarem działań rewitalizacyjnych podjętych przez Miasto ${ }^{6}$. W ramach renowacji przeprowadzonej w latach 1995-1999 przeprowadzono Projekt demonstracyjny renowacji ekologicznej dofinansowany ze środków rządu holenderskiego ${ }^{7}$. Opracowanie założeń i koncepcji ekologicznej renowacji dla projektu powierzono zespołowi naukowo-badawczemu złożonemu z pracowników Politechniki Szczecińskiej pod kierunkiem prof. dra hab. inż. arch. Marka Adama Wołoszyna, który opracował w 1999 r. raport końcowy Projekt demonstracyjny renowacji ekologicznej w Kwartale nr 27 Turzyńskim w Szczecinie. W projekcie zastosowano ekologiczne rozwiązania w zakresie ograniczenia zużycia wody i energii, pozyskania energii ze źródeł odnawialnych (panele słoneczne i fotowoltaiczne) oraz zastosowania materiałów i technologii budowlanych z uwzględnieniem metody oceny oddziaływania na środowisko ich całego cyklu życiowego - LCA ${ }^{8}$.

Na terenie kwartału nr 27 pierwsze kamienice remontowano ze środków budżetu miejskiego, dopiero uchwalenie dwóch ustaw: ustawy o własności lokali ${ }^{9}$, która wprowadzała możliwość współfinansowania renowacji części wspólnych przez właścicieli lokali oraz 
ustawy o niektórych formach popierania budownictwa mieszkaniowego ${ }^{10}$ dającej możliwość pozyskiwania kredytów przez towarzystwa budownictwa społecznego od Krajowego Funduszu Mieszkaniowego, wprowadziło nowe narzędzia finansowania. W 1997 r. w związku ze zmianami ustawowymi zarządzanie pracami powierzono spółce miejskiej STBS. W ramach obowiązków Spółka prowadziła negocjacje z mieszkańcami w kwestii mieszkań zamiennych oraz uruchomiła punkt informacyjny na terenie kwartału. W wyniku rewitalizacji, którą ukończono w 2008 r., przekształcono układ przestrzenny całego kwartału, przebudowano oficyny poprawiając nasłonecznienie i przewietrzanie mieszkań, zagospodarowano zielone dziedzińce i wyposażono w plac zabaw i spotkań integracyjnych oraz powiększono zasób mieszkań poprzez wzniesienie zabudowy „plombowej”. Tylko część mieszkańców wróciła do swoich lokali po ukończeniu remontu, pozostali przeprowadzili się do innych mieszkań komunalnych. Natomiast z właścicielami mieszkań zawarto indywidualne umowy rozliczające koszty renowacji ich lokali oraz części wspólnych ${ }^{11}$. Niestety kalkulacja kosztów inwestycji w formie czynszów lokatorskich niewątpliwie utrudniła dostęp rodzin o słabszej kondycji finansowej do puli mieszkań w zrewitalizowanym kwartale.

Doświadczenia zdobyte przez STBS podczas realizacji pilotażowego programu rewitalizacji kwartału nr 27 zostały wykorzystane przez Spółkę podczas kolejnych prac prowadzonych w kwartałach śródmiejskich nr 23, 33, 36 i 40.

Kwartał nr 33 wyznaczono do kompleksowej rewitalizacji już w 1996 r., ale pierwsze dwa budynki poddano renowacji dopiero w 2000 r. Zastosowano tutaj odmienny model finansowania wybrany ze względu na dużą liczbę mieszkań własnościowych w obrębie kwartału. W pozyskiwaniu funduszy wykorzystano Program „Nasz Dom” należący do pakietu miejskich programów wspierających działania rewitalizacyjne i zarządzanych przez szczeciński Zarząd Budynków i Lokali Komunalnych (ZBiLK) ${ }^{12}$. Prace w kwartale są kontynuowane, a ostatnią realizacją ukończoną w 2016 r. jest renowacja kamienicy przy ul. Chodkiewicza 8-9.

Kolejnym programem demonstracyjnym prowadzonym przez STBS było zainicjowanie termomodernizacji kwartału nr 36, którą realizowano w latach 2000-2004 w ramach Projektu Demonstracyjnego REGEN LINK. Program pod nazwą TERMOPOL był współfinansowany ze środków Unii Europejskiej. W ramach projektu STBS i wspólnoty mieszkaniowe jako Partnerzy otrzymali dotację w wysokości 30\% kosztów kwalifikowanych, różnicę pozyskując z Programu "Nasz Dom”, środków własnych oraz kredytów termomodernizacyjnych. Proces renowacji tego kwartału skupił się na działaniach proekologicznych oraz poprawiających jakość życia mieszkańców kamienic. Podjęte działania zmierzały do zmniejszenia zanieczyszczeń emitowanych do środowiska (likwidacji pieców gazowych), wykorzystania niekonwencjonalnych źródeł energii (użycie kolektorów słonecznych), ograniczenia wykorzystania energii (termomodernizacja budynków, wymiana stolarki okiennej na energooszczędną), podwyższenia standardów lokali (wykonanie instalacji c.o. i ciepłej wody bieżącej) oraz poprawienia estetyki budynków i otoczenia w wyniku wykonania remontów elewacji frontowych kamienic i zagospodarowania terenu wnętrz kwartału ${ }^{13}$. Obecnie w kwartale trwają 
prace nad programem Rewitalizacja „Bliżej przestrzeni 2016-2022”, w ramach których przeprowadzono ankietyzację oraz konkurs na opracowanie koncepcji urbanistyczno-architektonicznej.

Rewitalizacja kwartału nr 23 została przeprowadzona równie kompleksowo, jak w przypadku pilotażowego kwartału nr 27. W 2007 r. zainicjowano działania zmierzające do realizacji tej inwestycji. Spółka STBS podjęła współpracę ze wspólnotami mieszkaniowymi kwartału $\mathrm{nr} 23$, której owocem było stworzenie partnerskiego projektu Rewitalizacja RAZEM i pozyskanie środków Unii Europejskiej w ramach Regionalnego Programu Operacyjnego Województwa Zachodniopomorskiego (RPOWZ). Prace nad projektem rozpoczęto od opracowania koncepcji programowo-funkcjonalnej dla całego kwartału, którą prezentowano podczas konsultacji społecznych prowadzonych przez STBS od 2010 r. Ważnym elementem tych konsultacji było przedstawienie organizacji całego zamierzenia oraz oferty mieszkań zamiennych. W latach 2012-2014 w ramach Rewitalizacja RAZEM zrealizowano 3 projekty STBS: renowację części wspólnych budynków oficynowych; utworzenie świetlicy środowiskowej, punktu konsultacyjnego Miejskiego Ośrodka Pomocy Rodzinie w Szczecinie (MOPR), lokali usługowych oraz zagospodarowanie terenu; rozbudowę i przebudowę oficyn, budowę nowego budynku, utworzenie mieszkań dla osób starszych i mieszkań chronionych (mieszkania kryzysowe i „,inkubator"), oraz 7 projektów wspólnot mieszkaniowych w zakresie remontów elewacji frontowych, termomodernizacji elewacji tylnych, remontów dachów i bram przejściowych. Wnętrza kwartału uporządkowano i wyposażono w zieleń, plac zabaw oraz domki dla kotów, budki lęgowe dla ptaków i pojemniki na deszczówkę ustawione przy rynnach ${ }^{14}$.

Działania podjęte w kwartale nr 23 są działaniami wyjątkowymi, noszącymi znamiona rewitalizacji zintegrowanej, uwzględniającej nie tylko poprawę jakości przestrzeni i zabudowy kwartału, ale także poprawę jakości życia jego mieszkańców. Wydaje się, że w tej zrewitalizowanej przestrzeni udało się wprowadzić w życie koncepcję "przenikania się" różnych grup społecznych, co nie do końca powiodło się w „inicjacyjnym” kwartale nr 27.

Kwartałami należącym do zasobu drugiej spółki miejskiej TBSP, w których trwają działania renowacyjne są: kwartał nr 40 $0^{15}$ (od 2012 r.) i kwartał nr 39 (od 2015 r.). Prace w tych kwartałach prowadzone są zgodnie ze sprawdzoną formułą wypracowaną przez STBS.

\subsection{MODEL KOMERCYJNY REALIZOWANY POPRZEZ FINANSOWANIE KOMERCYJNE}

Do przeprowadzenia rewitalizacji w oparciu o model komercyjny wyznaczono kwartały $\mathrm{nr}$ 9, 12, 16, 21 i 22. Jako pierwsze poddano rewitalizacji kwartały $\mathrm{nr} 21,22$ z kamienicami usytuowanymi wzdłuż ul. Bogusława, czyli tzw. kwartały „norweskie”. Proces pozyskiwania partnera komercyjnego zakończył się w 1993 r. podpisaniem umowy z norweską firmą URGN. Jednak umowa ta nie przyniosła spodziewanych rezultatów, wobec czego Miasto w 1998 r. utworzyło spółkę STR z drugim udziałowcem, spółką American Retail System. W ramach tej współpracy zrealizowano renowację 4 kamienic w kwartale nr 22 
oraz wybudowano Deptak Bogusława ${ }^{16}$ rozciągający się wzdłuż ul. Księcia Bogusława X pomiędzy kwartałem nr 21 i 22. Konflikt interesów doprowadził do odsprzedania w 1999 r. przez Miasto swoich udziałów spółce STR i zastąpienia jej w dalszych działaniach rewitalizacyjnych spółką gminną SCR. Do 2008 r. SCR w ramach modelu budżetowego ukończyło rewitalizację kwartału nr 22, przechodząc do prac rewitalizacyjnych w kwartale $\mathrm{nr}$ 2177. W 2012 r. w momencie ważenia się losów SCR podpisana została umowa wstępna ze szwedzką firmą Lorenhill Centrum Development na sprzedaż 6 kamienic w kwartale nr 21. Inwestor komercyjny aktualnie prowadzi prace wzdłuż ul. Śląskiej 45-48 i ul. Obrońców Stalingradu 12-13.

\subsection{PROGRAMY WSPIERAJĄCE DZIAŁANIA REWITALIZACYJNE}

W ramach wspierania działań rewitalizacyjnych wypracowano kilka programów, które są adresowane do wspólnot mieszkaniowych i lokatorów. Są to: Program Małych Ulepszeń, Program „Nasz Dom” oraz Zielone Podwórka Szczecina zarządzane przez szczeciński ZBiLK. Wprowadzony w 1994 r. Program Małych Ulepszeń skierowany jest do najemców lokali komunalnych. W ramach tego programu dofinansowywane są: remonty lokali gminnych w formie budowy toalety, łazienki lub kuchni wraz z wykonaniem instalacji, zmiany ogrzewania z tradycyjnego na gazowe, elektryczne lub miejskiej sieci ciepłowniczej. Drugi program realizowany w latach 1998-2009 i adresowany do właścicieli mieszkań miał ich motywować do przeprowadzania remontów budynków. Niestety w wyniku wydania orzeczenia przez Naczelny Sąd Administracyjny program został zawieszony.

Ostatni program Zielone Podwórka Szczecina wprowadzony w 2008 r. wspiera finansowo rewitalizację podwórek i dziedzińców ${ }^{18}$.

W 2015 r. wprowadzono kolejny program Zielone Przedogródki Szczecina. W ramach projektu wspólnoty mieszkaniowe kamienic usytuowanych wzdłuż ulic z historycznymi przedgródkami uzyskały dotacje (75\%) na ich odtworzenie przy zachowaniu wspólnych standardów estetycznych ${ }^{19}$.

\section{PODSUMOWANIE}

Przykłady rewitalizacji przeprowadzonych w obszarze śródmiejskim Szczecina ukazują skalę problemów związanych z ich realizacją. Niestety, w przeciągu 26 lat od momentu zainicjowania prac nie zdołano przeprowadzić ich w obrębie całego wyznaczonego obszaru obejmującego 56 kwartałów. Jedynie w 3 kwartałach (kwartały nr 22, 23 i 27) ukończono rewitalizację, w kolejnych 5 (kwartały $\mathrm{nr} 21,33,36,39,40$ ) prace są mocno zaawansowane lub zmierzają ku ukończeniu. Suma ta nie jest imponująca, szczególnie gdy przywołamy fakt zrealizowania całej śródmiejskiej dzielnicy w przeciągu 30 lat pod koniec XIX w. 
Rewitalizacja kwartałów niezależnie od obranego modelu działania jest procesem długotrwałym. W przypadku modelu budżetowego jest to związane z wieloetapowością procedury wypracowanej przez towarzystwa budownictwa mieszkaniowego, w której projekt rewitalizacji kwartału poprzedzony jest konsultacjami społecznymi oraz konkursem na opracowanie koncepcji przestrzenno-architektonicznej. Elementy te są istotną podbudową w tworzeniu partnerstwa ze wspólnotami mieszkaniowymi i w opracowaniu wniosków o dofinansowanie zarówno zewnętrzne, jak i krajowe.

W sytuacji modelu komercyjnego często proces rewitalizacji ulega wydłużeniu w skutek braku rygoru, jakim jest rozliczanie się w ramach programów unijnych i krajowych oraz konfliktu interesów pomiędzy miastem a prywatnym kapitałem zmierzającym do optymalizowania zysków.

O ile model budżetowy sprawdził się w warunkach szczecińskich, o tyle model komercyjny dostarcza wielu trudności, zaczynając do pozyskania inwestora komercyjnego poprzez ukończenie realizacji w terminie. Ponadto w modelu komercyjnym realizowanym w Szczecinie niestety pominięto aspekt społeczny, który razem z czynnikiem ekonomicznym i przestrzennym stanowi niezbędny element przeprowadzenia udanej rewitalizacji.

Rewitalizacja jest zadaniem publicznym angażującym interesariuszy tego procesu, wśród których znaleźć się powinni obok podmiotów publicznych również sami mieszkańcy rewitalizowanych obszarów. Najnowsza ustawa o rewitalizacji z 9 października 2015 r. kładzie duży nacisk na partycypację społeczną, która obecnie ma zdecydowanie przewyższać dotychczasowe praktyki związane z konsultacjami społecznymi oraz nakłada obowiązek powołania Komitetu Rewitalizacji (KR), który w swym gronie zawierać ma miedzy innymi przedstawicieli interesariuszy. W myśl nowej ustawy KR ma stać się rodzajem platformy dialogu mieszkańców z organami gminy. Dotychczas prowadzone w Szczecinie konsultacje społeczne w powszechnej ocenie miały fasadowy charakter nie przekładając się na wymierny wkład interesariuszy w procesach rewitalizacyjnych. Gminny Program Rewitalizacji umożliwi uruchomienie takich narzędzi ustawowych jak uchwalenie dla miasta Szczecin miejscowego planu rewitalizacji, wyznaczenie Specjalnej Strefy Rewitalizacji, wyznaczenie obszaru zdegradowanego i obszaru rewitalizacji. Obowiązujący obecnie w Szczecinie Lokalny Program Rewitalizacji odwołuje się do już nieaktualnych danych nie respektując założeń obowiązującego od 2015 r. Regionalnego Programu Operacyjnego Województwa Zachodniopomorskiego 2014-2020.

Wobec zaistniałych zmian ustawowych może niepokoić fakt koncentracji działań rewitalizujących szczecińskie śródmieście jedynie w granicach poszczególnych kwartałów, z pominięciem kompleksowego rozwiązania problemów zurbanizowanej przestrzeni dzielnicy. Dotyczy to w szczególności braku systemowych rozwiązań odnośnie parkowania (pomimo wprowadzenie płatnej strefy parkowania w dzielnicy dostrzec można ogromny problem z parkowaniem), udrożnienia ruchu ulicznego oraz gospodarczego rozwoju dzielnicy (problem z dekomercjalizacją, czyli odpływem z centrum miasta usług i handlu oraz „wyssaniem” tego typu usług przez 2 centra handlowo-usługowe zlokalizowane w bezpośrednim sąsiedztwie śródmiejskiej dzielnicy). 
Ważnym elementem szczecińskiej rewitalizacji, obok obu modeli współpracy: budżetowego i publicznego, jest inicjowanie działań lokalnych społeczności w ramach programów wspierających prace rewitalizacyjne. Znaczenie tych działań można docenić za sprawą programów zmierzających do estetyzacji przestrzeni wnętrz ulicznych, jak modernizacje elewacji i renowacje przedogródków, które szybko przyniosły wymierny efekt w postaci poprawy jakości przestrzeni miejskiej.

Rewitalizację szczecińskiej dzielnicy śródmiejskiej wielokrotnie nagradzano ${ }^{20}$, a w 2016 r. Ministerstwo Rozwoju wskazało jako przykład dobrej praktyki ${ }^{21}$ i pomimo dostrzegalnych mankamentów, należy uznać ją za właściwy, acz powolny krok, w stronę „wydobycia określonej przestrzeni miejskiej, dzielnicy, kwartału z głębokiej, (...) katastrofalnej zapaści”22. 


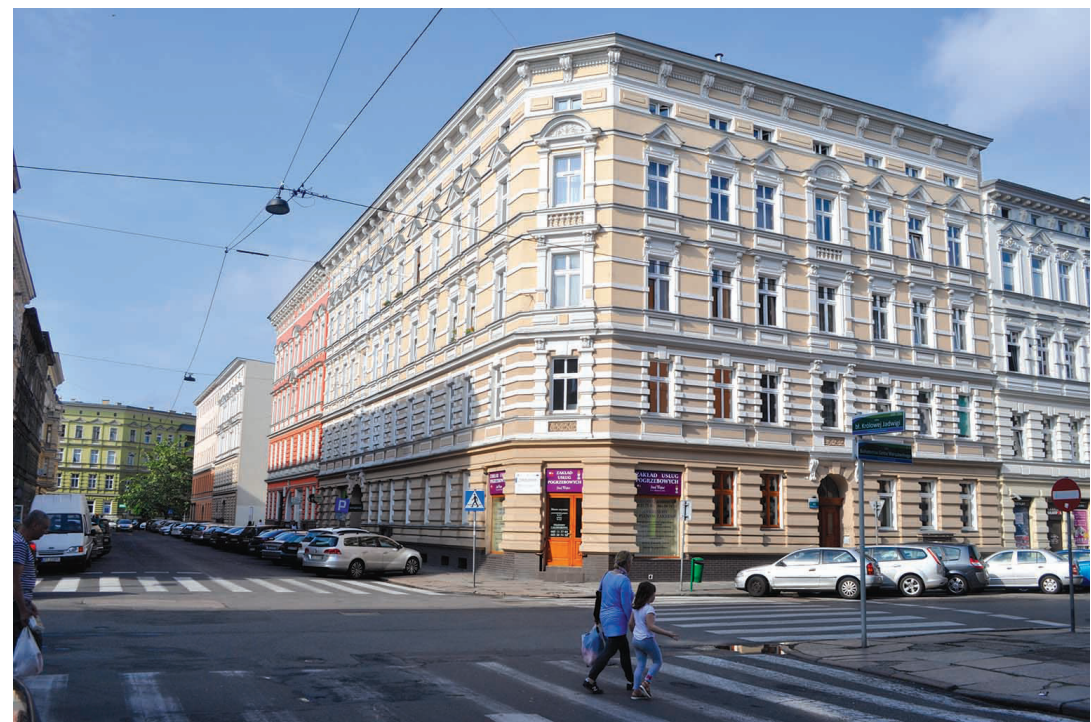

II. 1. Kwartał nr 23 po rewitalizacji - skrzyżowanie ul. Bohaterów Getta Warszawskiego z ul. Królowej Jadwigi (fot. I. Kozłowska)

III. 1. The Block 23 after the revitalization - the cross streets Bohaterów Getta Warszawskiego with Królowej Jadwigi

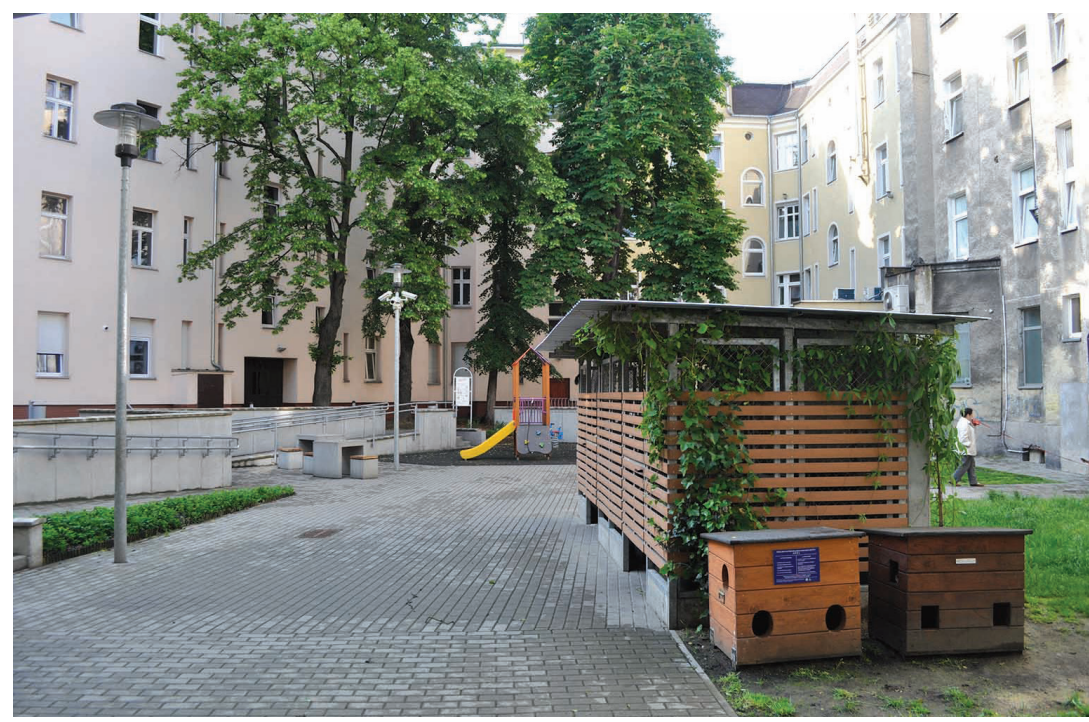

II. 2. Nowe zagospodarowanie wnętrza kwartału nr 23 z placem zabaw i budkami dla kotów

(fot. I. Kozłowska)

III. 2. The new interior development of Block 23 with the playground and the cat's sheds 


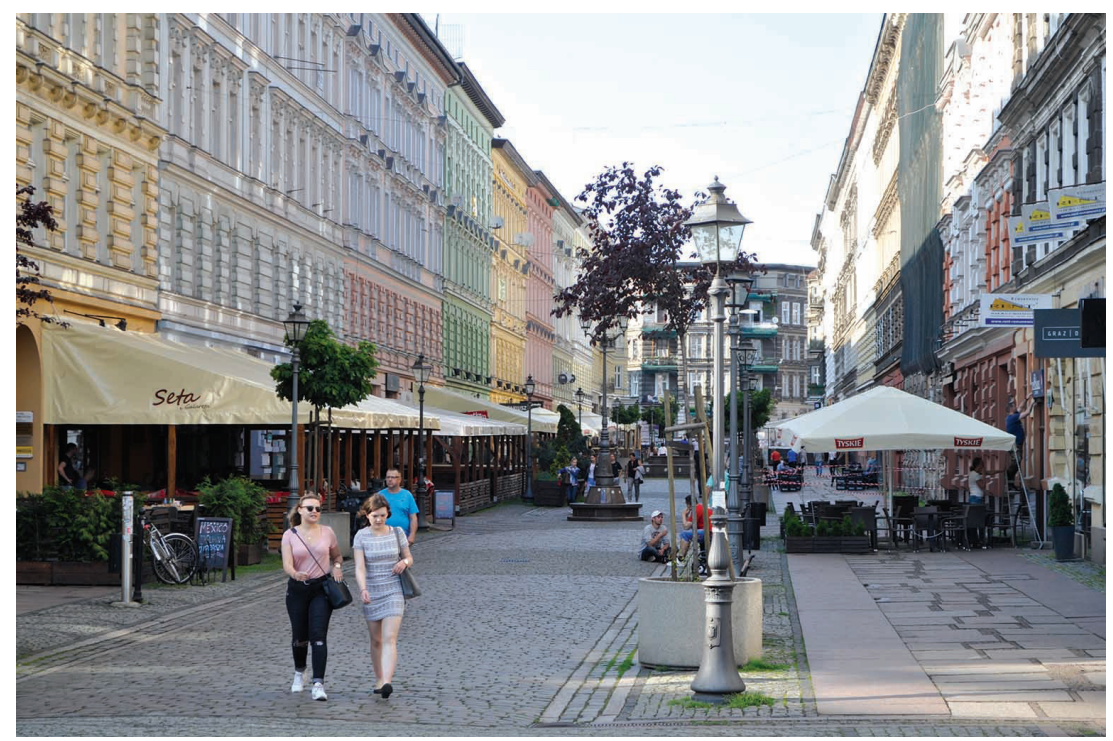

II. 3. Deptak Bogusława - widok od strony pl. Zgody (fot. I. Kozłowska)

III. 3. Bogusława Prom - the view from the Zgody Square

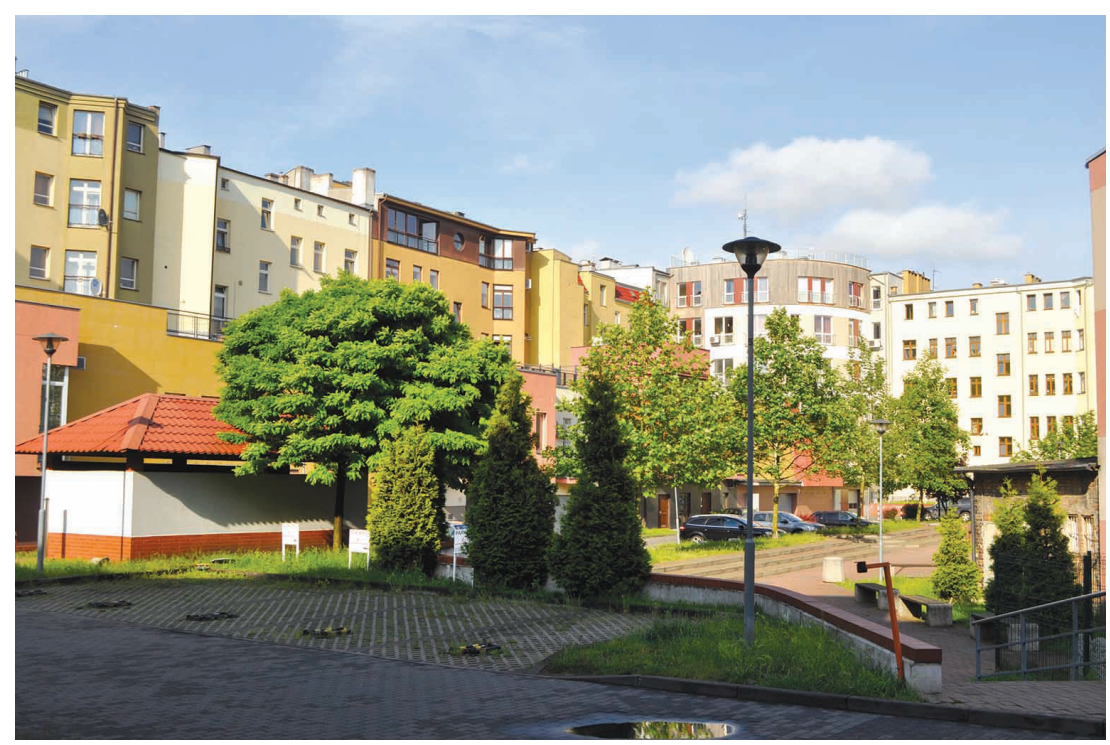

II. 4. Wnętrze kwartału nr 22 po rewitalizacji - nowa zabudowa oficynowa kamienic przy ul. Jagiellońskiej (fot. I. Kozłowska)

III. 4. The interior development of Block 22 after the revitalization - the new buildings of the tenement houses on Jagiellońska Street 


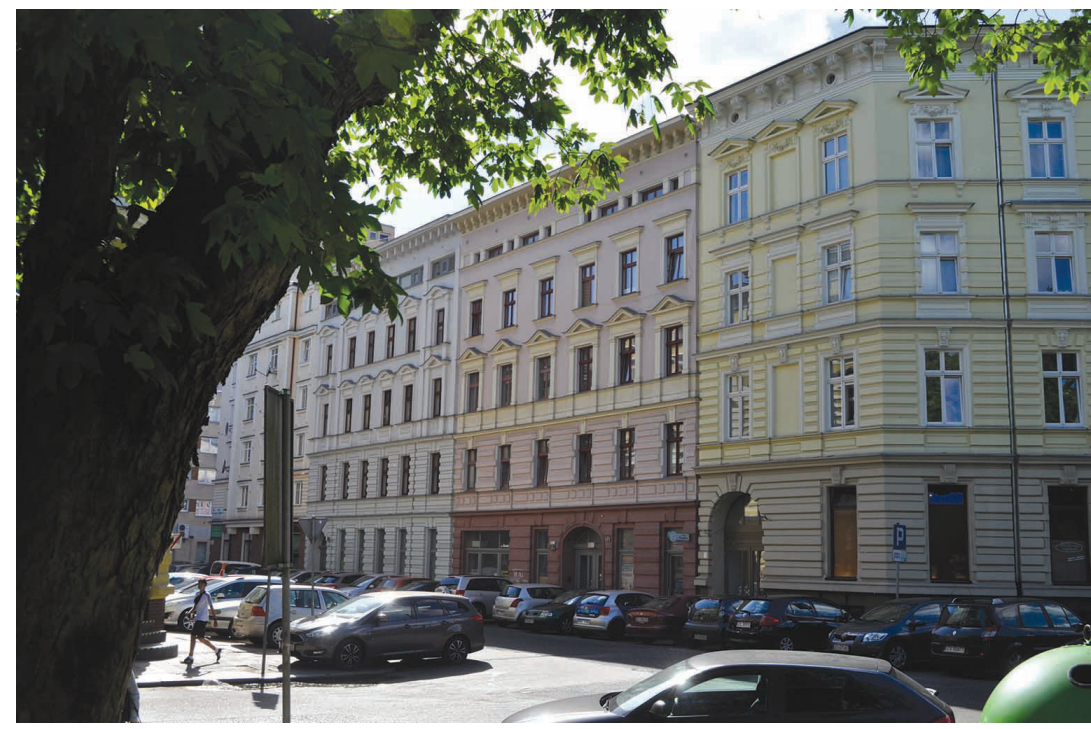

II. 5. Kwartał nr 40 - skrzyżowanie ul. Śląskiej z ul. Więckowskiego (fot. I. Kozłowska) III. 5. The Block 40 - the cross streets Śląska with Więckowskiego

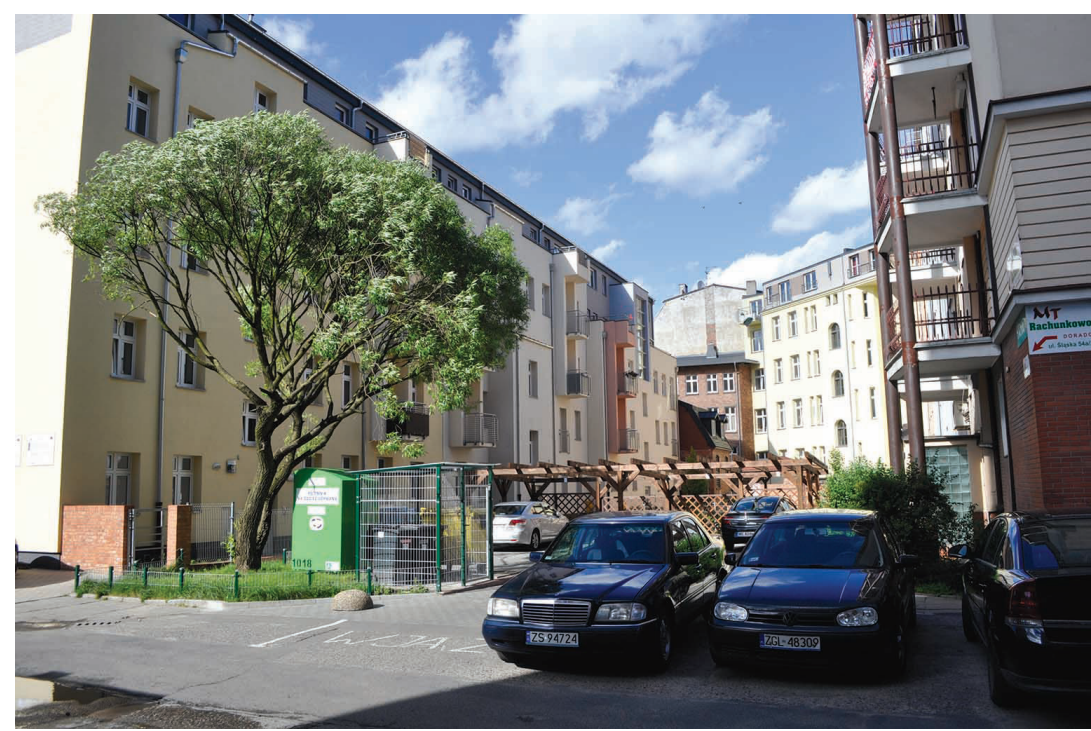

II. 6. Wnętrze kwartału nr 40 po rewitalizacji - nowa zabudowa oficynowa kamienic przy ul. Śląskiej (fot. I. Kozłowska)

III. 6. The interior development of Block 40 after the revitalization - the new buildings of the tenement houses on Śląska Street 


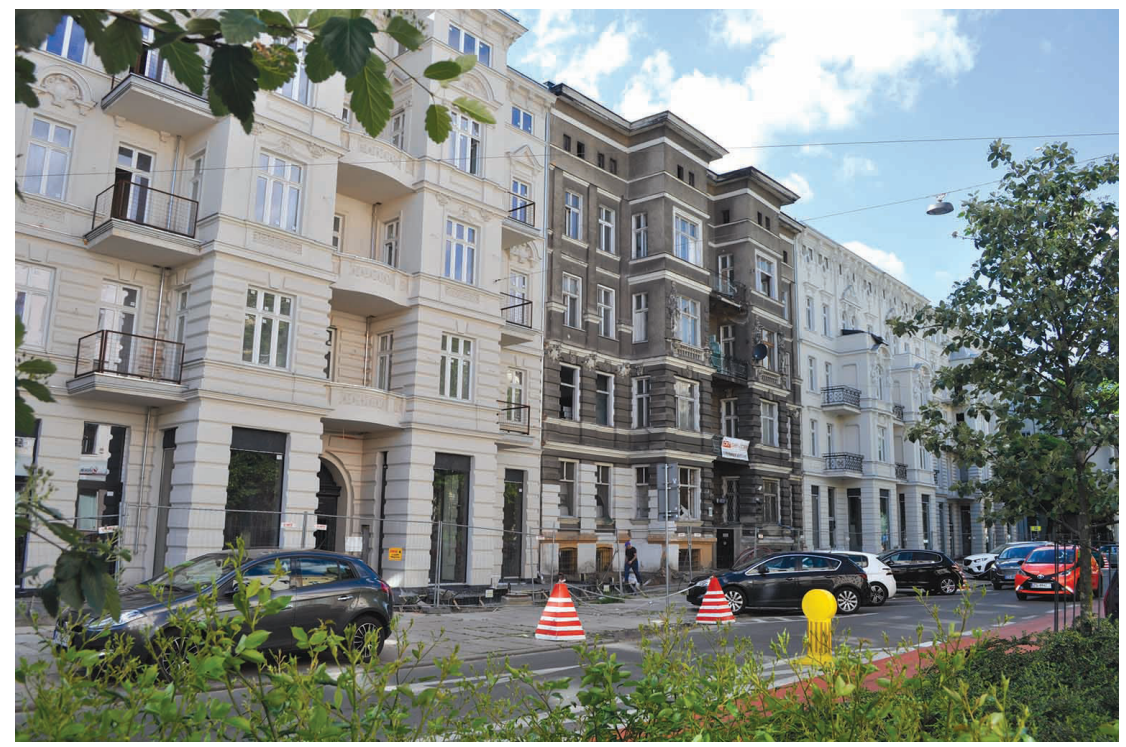

II. 7. Kwartał nr 21 w trakcie rewitalizacji - widok od ul. Śląskiej (fot. I. Kozłowska) III. 7. The Block 21 during the revitalization - the view from Śląska Street

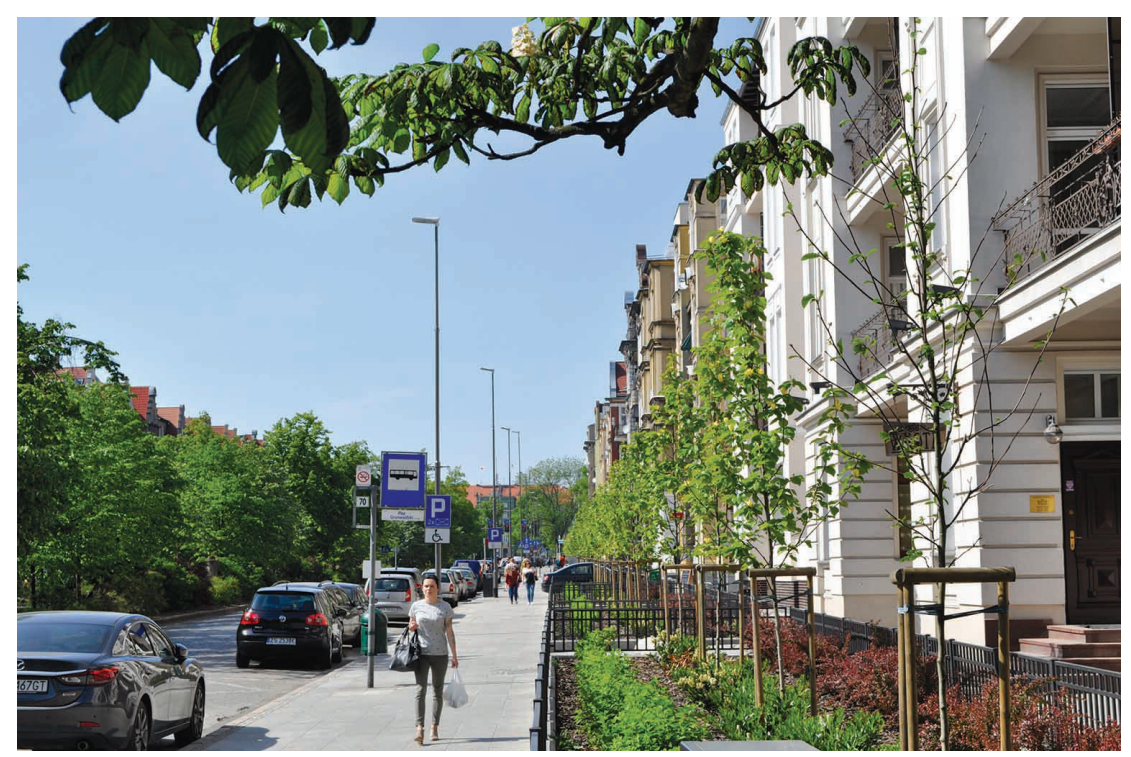

II. 8. Aleja Papieża Jana Pawła II - przedogródki po renowacji przeprowadzonej w ramach programu Zielone Przedogródki Szczecina (fot. I. Kozłowska)

III. 8. Avenue Papież Jan Paweł II - the gardens in front of the tenement houses - the gardens after the revitalization carried out within the program Zielone Przedogródki Szczecina 


\section{PRZYPISY}

1 Z. Paszkowski, K. Bizio, Rewitalizacja w obliczu depopulacji miast, [w:] Monografia Awarie Budowlane. Zapobieganie, diagnostyka, naprawa, rekonstrukcje, M. Kaczyńska (red.), Wydawnictwo Zachodniopomorskiego Uniwersytetu Technologicznego w Szczecinie, Szczecin 2017, s. 93.

2 Ludzie - Przestrzeń - Zmiana. Dobre praktyki w rewitalizacji polskich miast, s. 59, https:// www.mr.gov.pl/media/22237/dobre_praktyjki_rewitalizacja.pdf (dostęp: 25.05.2017).

3 Lokalny Program Rewitalizacji dla Miasta Szczecina, http://bip.um.szczecin.pl/UMSzczecinFiles/file/projekt_257_zal.pdf (dostęp: 25.05.2017).

4 Ibidem, s. 23.

5 Ibidem, s. 160.

6 Projekt został wykonany przez biuro architektoniczne STUDIO A4 Spółka Projektowa z o.o.

7 Lokalny Program..., op. cit., s. 60.

8 R. Mazur, Rozwiqzania energooszczędne na przykładzie rewitalizacji zabudowy czynszowej z XIX wieku w Szczecinie, „Zeszyty Naukowe Politechniki Śląskiej”, Seria: Architektura z. 51/2012, s. 66-67.

9 Ustawa z dnia 24 czerwca 1994 r. o własności lokali, Dz.U. 1994 nr 85, poz. 388.

10 Ustawa z dnia 26 października 1995 r. o niektórych formach popierania budownictwa mieszkaniowego oraz o zmianie niektórych ustaw, Dz.U. 1995 nr 133 poz. 654.

11 Lokalny Program..., op. cit., s. 60.

12 http://www.stbs.pl/index.php/dzialalnosc/renowacje-i-rewitalizacje/kwartal-33 (access: 25.05.2017).

${ }^{13}$ http://www.stbs.pl/index.php/dzialalnosc/renowacje-i-rewitalizacje/rewitalizacja-kwartalow-srodmiejskich/termorenowacja-kwartalu-36 (access: 25.05.2017).

${ }^{14}$ http://www.stbs.pl/index.php/rewitalizacja-razem (access: 25.05.2017).

${ }^{15}$ http://www.szczecin.pl/files/DD8F9B47EE294F60B639ED523AC409AB/MATERIA\% C5\%81Y\%20-\%200\%20inwestycji.pdf (access: 25.05.2017).

16 Projekty wykonała Autorska Pracowni Projektowa URBICON Sp. Z o.o. prowadzona przez prof. zw. dr hab. inż. arch. Zbigniewa Paszkowskiego.

17 Lokalny Program..., op. cit., s. 161.

18 Ludzie - Przestrzeń..., op. cit., s. 61.

$19 \mathrm{http}: / /$ zbilk.szczecin.pl/?type=article\&action=view\&id=897 (access: 25.05.2017).

${ }^{20}$ http://www.stbs.pl/index.php/o-nas/wyroznienia-i-nagrody (access: 25.05.2017).

${ }^{21}$ Ludzie - Przestrzeń..., op. cit.

22 Z. Paszkowski, K. Bizio, Rewitalizacja..., op. cit., s. 94. 


\section{BIBLIOGRAFIA}

Kozińska B., Rozwój przestrzenny Szczecina od poczq̨tku XIX wieku do II wojny światowej, KAMPOL 2, Szczecin 2002.

Lokalny Program Rewitalizacji dla Miasta Szczecina, http://bip.um.szczecin.pl/UMSzczecinFiles/file/projekt_257_zal.pdf (dostęp: 25.05.2017).

Lokalny Program Rewitalizacji obszarów miejskich, poprzemysłowych i powojskowych miasta Szczecina, http://www.szczecin.pl/Strategia/_pl/uchwalone/lokalny_program_rewitalizacji.pdf (dostęp: 25.05.2017).

Ludzie - Przestrzeń - Zmiana. Dobre praktyki w rewitalizacji polskich miast, https://www. mr.gov.pl/media/22237/dobre_praktyjki_rewitalizacja.pdf (dostęp: 25.05.2017).

Mazur R., Rozwiqzania energooszczędne na przykładzie rewitalizacji zabudowy czynszowej z XIX wieku w Szczecinie, „Zeszyty Naukowe Politechniki Śląskiej”, Seria: Architektura z. 51/2012, s. 61-69.

Paszkowski Z., Bizio K., Rewitalizacja w obliczu depopulacji miast, [w:] Monografia Awarie Budowlane. Zapobieganie, diagnostyka, naprawa, rekonstrukcje, M. Kaczyńska (red.), Wydawnictwo Zachodniopomorskiego Uniwersytetu Technologicznego w Szczecinie, Szczecin 2017.

Świątek L., Studium przypadku. Projekt demonstracyjny renowacji ekologicznej Kwartału Turzyńskiego w Szczecinie, [w:] Wyzwania zrównoważonego rozwoju w Polsce, J. Kronenberg, T. Bergier (red.), Fundacja Sendzimira, Kraków 2010.

Wołoszyn M.A., Ekorewitalizacja-zagadnienia architektoniczne, Exemplum, Poznań-Szczecin 2013. 